\title{
Case report: Intraoperative anaphylactoid reaction and hydroxyethyl starch in balanced electrolyte solution (Hextend®)
}

\author{
[Présentation de cas : réaction anaphylactoïde peropératoire et amidon \\ bydroxyéthylé dans une solution d'électrolyte balancée (Hextend®)]
}

Brian A. Hall MD, ${ }^{*}$ Evangelo Frigas MD,$\dagger$ Damir Matesic MD $\nmid \nmid$ Michael D. Gillett MD, $\ddagger$ Juraj Sprung MD PhD*

Purpose: To report a first case of probable anaphylactoid reaction to $6 \%$ hydroxyethyl starch reconstituted in balanced electrolyte and glucose solution (Hextend ${ }^{\circledR}$ ).

Clinical features: A 22-yr-old man was admitted for a partial nephrectomy. Near the end of the four-hour operation, an infusion of Hextend ${ }^{\circledR}$ was initiated. Shortly thereafter, mechanical ventilation became difficult, peak inspiratory pressure increased to $55 \mathrm{~cm} \mathrm{H}_{2} \mathrm{O}$ with audible wheezing over the patient's lungs. Blood pressure suddenly decreased to $68 / 46$ $\mathrm{mmHg}$. Multiple doses of phenylephrine, ephedrine and epinephrine were required to restore the patient's blood pressure. Postoperatively, a diffuse urticarial rash was apparent on his upper torso. The patient recovered uneventfully. His postoperative serum tryptase was $26.3 \mathrm{ng} \cdot \mathrm{mL}^{-1}$ (reference range, $<$ II.5 ng. $\mathrm{mL}^{-1}$ ) and the urine $\mathrm{N}$-methyl-histamine was 2448 $\mu \mathrm{g} \cdot \mathrm{g}^{-1}$ creatinine (reference range, $30-200 \mu \mathrm{g} \cdot \mathrm{g}^{-1}$ creatinine). Two months after the event, skin testing was conducted to test for possible allergy to latex, lidocaine, propofol, cisatracurium, succinylcholine, vecuronium, midazolam, fentanyl, ondansetron, neostigmine, and cephazolin, and all were negative. Hextend ${ }^{\circledR}$ was also tested, starting with a 1:100,000 dilution and the results were negative.

Conclusions: The temporal relationship of severe hypotension, bronchospasm and skin rash within ten minutes from administration of Hextend ${ }^{\circledR}$ in this patient suggests an immediate hypersensitivity reaction to hetastarch. The elevated levels of serum tryptase and urinary $\mathrm{N}$-methyl-histamine suggest that this hypersensitivity was mediated from mast cell degranulation. Negative skin testing suggests that the reaction was anaphylactoid.
Objectif: Présenter un premier cas de réaction anaphylactoïde probable à de l'amidon hydroxyéthylé reconstitué à $6 \%$ dans une solution de glucose et d'électrolyte balancée (Hextend $\AA$ ).

Éléments cliniques: Un homme de 22 ans a été admis pour une néphrectomie partielle. Vers la fin de l'opération de quatre heures, une perfusion d'Hextend ${ }^{\circledR}$ a été amorcée. Peu après, la ventilation mécanique est devenue difficile, la pression inspiratoire maximale est montée à $55 \mathrm{~cm} \mathrm{H}_{2} \mathrm{O}$ et s'accompagnait de sifflement perceptible à l'auscultation des poumons. La tension artérielle a soudainement chuté à $68 / 46 \mathrm{mmHg}$. De multiples doses de phényléphrine, d'éphédrine et d'épinéphrine ont été nécessaires pour restaurer la tension artérielle du patient. Après l'opération, une éruption urticarienne était apparente à la partie supérieure du torse. Une récupération sans incident a suivi. La tryptase sérique postopératoire a été de $26,3 \mathrm{ng} \cdot \mathrm{mL}^{-1}$ (étendue de référence, $<|1| .5 \mathrm{ng} \cdot \mathrm{mL}^{-1}$ ) et la $\mathrm{N}$-méthyl-histamine urinaire $a$ été de $2448 \mu \mathrm{g} \cdot \mathrm{g}^{-1}$ de créatinine (étendue de référence, 30-200 $\mu \mathrm{g} \cdot \mathrm{g}^{-1}$ de créatinine). Deux mois après l'événement, des tests d'allergie cutanée au latex, à la lidocaïne, au propofol, au cisatracurium, à la succinylcholine, au vécuronium, au midazolam, au fentanyl, à l'ondansétron, à la néostigmine et à la céphazoline ont été menés et se sont tous révélés négatifs. Le Hextend ${ }^{\circledR}$ $a$ été aussi testé, en commençant avec une dilution à $1: 100000$ et les résultats ont été négatifs. Conclusion: La relation temporelle entre l'hypotension sévère, le bronchospasme et l'éruption cutanée en moins de dix minutes après l'administration du Hextend $\AA$ laisse croire à une réaction d'hypersensibilité immédiate à l'hétamidon. Les niveaux élevés de tryptase sérique et de $\mathrm{N}$-méthyl-histamine urinaire indiquent que cette hypersensibilité origine d'une dégranulation des basophiles. Les tests cutanés négatifs montrent que la réaction était anaphylactoïde.

From the Department of Anesthesiology, ${ }^{*}$ the Division of Allergic Diseases and Internal Medicine, $†$ and the Department of Urology, $\ddagger$ Mayo Clinic College of Medicine, Rochester, Minnesota, USA. Address correspondence to: Dr. Juraj Sprung, Professor of Anesthesiology, Department of Anesthesiology, Mayo Clinic College of

Medicine, 200 First Street SW, Rochester, MN 55905, USA. Phone: 507-255-3298; Fax: 507-255-6463; E-mail: Sprung.juraj@mayo.edu Support for this study is provided from the Department of Anesthesiology and Division of allergic Diseases and Internal Medicine,

Mayo Clinic, Rochester, MN, USA.

Accepted for publication May 23, 2006.

Revision accepted June 14, 2006.

Competing interests: None declared. 
$\mathrm{H}$

YDROXYETHYL starch (HES), a synthetic colloid derived from amylopectin, consists of hydroxyethylated polymers of glucose. The physical characteristics of hydroxyethyl starch can be described by their average molecular weight (MW) and their molar substitution ratio (i.e., the ratio of replacement of glucose by hydroxyethyl group). For example, hetastarch has an average $\mathrm{MW}$ of $450 \mathrm{kDa}$ with a molar substitution of 0.7 , therefore it is labelled $450 / 0.7$. Pentastarch, labelled as $200 / 0.5$, is a low MW (average 200 $\mathrm{kDa}$ ) product with a lower molar substitution $(0.5)$. Hespan $^{\circledR}$ (Hospira, Inc., Lake Forest, IL, USA; 6\% hetastarch in $0.9 \%$ sodium chloride) has an average MW $600 \mathrm{kDa}$, and molar substitution of approximately $0.75(600 / 0.75)$. Hextend ${ }^{\circledR}$ (BioTime, Inc., Berkeley, CA, USA), is a high MW (average $670 \mathrm{kDa}$ ) $6 \%$ hydroxyethyl starch, reconstituted in balanced electrolyte and glucose solution, with molar substitution ratio of 0.75 , and is labelled $670 / 0.75 .^{1,2}$

Due to their established efficacy in replenishing intravascular volume, HES solutions are widely used to treat hypovolemia. However, their use is not free from the risk of allergic reactions, ${ }^{3}$ which is estimated to $0.0004 \%,{ }^{4}$ and the risk of life-threatening reactions is reported to be $0.006 \% .^{5}$ The clinical picture of allergic reactions to HES may range from skin manifestations to severe and life-threatening complications. While allergic reactions to lower MW hydroxyethyl starches have been reported, ${ }^{6-9}$ we present a patient who developed a severe intraoperative allergic reaction soon after initiation of high MW hetastarch, Hextend ${ }^{\circledR}$ infusion. This patient's high postoperative serum tryptase concentration initially suggested anaphylaxis, but subsequent skin testing excluded an IgE-mediated mechanism and suggested an anaphylactoid reaction.

\section{Case report}

With the approval of the Mayo Clinic Institutional Review Board Ethics Committee, a retrospective review of our patient's medical records was conducted. A 22-yr-old, 65-kg male, was admitted for partial nephrectomy due to hydronephrosis of the upper pole of his right kidney secondary to duplication of the right kidney urinary collection system. His medical history was significant for mild hypertension and asthma. His only home medication was albuterol, used occasionally for "chest tightness," which he had not required before surgery. He reported codeine as his only allergy. He had no prior surgical history.

The patient's pre-induction blood pressure and heart rate were $114 / 56 \mathrm{mmHg}$ and 67 beats. $\mathrm{min}^{-1}$ respectively. A $16-\mathrm{G}$ peripheral $i v$ line was placed prior to an uneventful induction which was achieved with fentanyl, midazolam, propofol and lidocaine. Tracheal intubation was facilitated with a defasciculating dose of vecuronium $0.7 \mathrm{mg} i v$ followed by succinylcholine $120 \mathrm{mg} i v$. Immediately after induction of anesthesia, cephazolin $1000 \mathrm{mg} i v$ was administered uneventfully. Following induction, anesthesia was maintained with isoflurane and the patient's lungs were ventilated to eucarbia with $50 \%$ oxygen mixed with air. A $14-\mathrm{G}$ peripheral in line was inserted, as well as a left $20-\mathrm{G}$ arterial radial catheter. The blood pressure following induction was $120 / 75 \mathrm{mmHg}$, and heart rate was 85 beats. $\mathrm{min}^{-1}$. The patient's hemodynamic course remained stable throughout the first three hours of the procedure, during which cisatracurium and incremental doses of oxymorphone were administered as required to maintain muscle relaxation and analgesia, respectively. The estimated blood loss was $550 \mathrm{~mL}$. Approximately $45 \mathrm{~min}$ before the end of the operation a second dose of cefazolin $1000 \mathrm{mg} i v$ was given. Ten minutes before the end of surgery, the anesthesiologist began an infusion of hydroxyethyl starch $\left(\right.$ Hextend $\left.^{\circledR}\right)$ to augment the patient's intravascular volume. Within minutes of initiation of the HES infusion, and after approximately $200 \mathrm{~mL}$ were given, mechanical ventilation became difficult; peak inspiratory pressures increased to $55 \mathrm{~cm} \mathrm{H}_{2} \mathrm{O}$ in association with up-sloping (phase III) of the capnographic tracing. Attempts at manual ventilation became increasingly difficult. Assessment of the anesthetic machine, anesthesia circuit and endotracheal tube revealed no evidence of mechanical obstruction. At this point the patient's blood pressure had decreased to $68 / 46 \mathrm{mmHg}$, and he was in normal sinus rhythm at 96 beats. $\mathrm{min}^{-1}$, with an $\mathrm{O}_{2}$ saturation of $93 \%$. The end-tidal $\mathrm{CO}_{2}$ decreased abruptly from $29 \mathrm{mmHg}$ to $13 \mathrm{mmHg}$. It was evident that the patient was experiencing a severe allergic reaction, most likely related to hetastarch, and the infusion was therefore discontinued. The patient's ventilation was switched to $100 \% \mathrm{O}_{2}$ and albuterol $270 \mu \mathrm{g}$ was administered via a metered dose inhaler through the endotracheal tube. Simultaneously, multiple boluses of phenylephrine (cumulative dose 1300 $\mu \mathrm{g} i v)$, and ephedrine (10 $\mathrm{mg}$ iv increments) were administered, in conjunction with isotonic crystalloid. In view of the patient's continued hypotension, epinephrine was administered in $10 \mu \mathrm{g}$ iv increments (cumulative dose $60 \mu \mathrm{g}$ ). Within ten minutes, the combine defects of epinephrine and lactated Ringer's solution $2.5 \mathrm{~L}$ restored the patient's blood pressure to $163 / 87 \mathrm{mmHg}$ and heart to $109-125$ beats. $\mathrm{min}^{-1}$. Diphenhydramine $50 \mathrm{mg} i v$ and dexamethasone $16 \mathrm{mg}$ iv were administered. After restoration of blood pres- 
sure the patient's oxyhemoglobin saturation remained $>97 \%$ and his end-tidal $\mathrm{CO}_{2}$ ranged between 26 and $34 \mathrm{mmHg}$, while peak ventilatory pressures decreased gradually to $16 \mathrm{mmHg}$. As the patient's condition had stabilized, residual neuromuscular block was reversed with neostigmine $4 \mathrm{mg} i v$ and glycopyrrolate $0.6 \mathrm{mg}$ $i v$, and isoflurane was discontinued. When the surgical drapes were removed, a diffuse urticarial skin rash was evident over the patient's face and upper thorax. These cutaneous manifestations resolved spontaneously within eight hours. The patient's trachea was extubated uneventfully in the postanesthesia care unit one hour following completion of surgery.

In follow-up to the intraoperative events, blood samples were taken in the immediate postoperative period for laboratory investigation. The patient's serum tryptase concentration was $26.3 \mathrm{ng} \cdot \mathrm{mL}^{-1}$ (nor$\left.\mathrm{mal},<11.5 \mathrm{ng} \cdot \mathrm{mL}^{-1}\right)$, his serum histamine was 1.7 $\mathrm{ng} \cdot \mathrm{mL}^{-1}$ (normal $<1.0 \mathrm{ng} \cdot \mathrm{mL}^{-1}$ ), and the urine $\mathrm{N}$ methyl-histamine was $2448 \mu \mathrm{g} \cdot \mathrm{g}^{-1}$ creatinine (random sample) [normal, 30-200 $\mu \mathrm{g} \cdot \mathrm{g}^{-1}$ creatinine]. Two months later, the patient returned for allergy skin testing. Histamine skin prick test $\left(6 \mathrm{mg} \cdot \mathrm{mL}^{-1}\right)$ at 15 min resulted in the expected wheal $(7 \times 10 \mathrm{~mm})$ and flare $(10 \times 10 \mathrm{~mm})$. Skin tests were performed for latex, lidocaine, propofol, cisatracurium, succinylcholine, vecuronium, midazolam, fentanyl, ondansetron, neostigmine, and cephazolin, and were all negative. Hextend ${ }^{\circledR}$, the presumed culprit of this patient's allergic reaction, was also tested, starting with a 1:100,000 dilution and repeated up to neat (undiluted) solution, again with negative results.

\section{Discussion}

We describe a patient who experienced intraoperative mast-cell degranulation (elevated serum tryptase) associated with cardiovascular collapse within ten minutes from the start of an infusion of $6 \%$ hetastarch $(670 / 0.75)$. While a cause-effect relationship cannot be proven, the absence of any other iv medications or exposure to other potential allergens in the $45 \mathrm{~min}$ prior to the acute event strongly suggests an association with the $6 \%$ hetastarch solution. The positive predictive value of increased serum tryptase for the diagnosis of anaphylaxis is $92.6 \%$; the negative predictive value is $54.3 \% .{ }^{10}$ Subsequent negative allergy skin testing with hetastarch suggested that this patient may have experienced a non-IgE mediated, anaphylactoid reaction.

Several instances of hypersensitivity reactions to hydroxyethyl starch have been reported., ${ }^{411-14}$ Most of these reactions, however, were implicated with lower MW/lower substitution ratio compounds. ${ }^{6-9,15}$ Kannan et al. ${ }^{15}$ and Ebo et al. ${ }^{8}$ described reaction to 200/0.5 pentastarch, McHugh et al. ${ }^{9}$ to pentastarch $250 / 0.45$, and Kreimeier et al. ${ }^{6}$ to $10 \%$ pentastarch $(200 / 0.5)$. Our case represents a first report of probable anaphylactoid reaction to Hextend ${ }^{\circledR}$, a higher $\mathrm{MW} /$ higher substitution rate $(670 / 0 / 75) 6 \%$ hetastarch.

In general, hypotension followed by bronchospasm are the first manifestations of anaphylaxis during anesthesia. ${ }^{16}$ Typically, bronchospasm is not a dominant sign of anaphylaxis during anesthesia, but atopic individuals (asthmatics), such was this patient, can experience both bronchospasm and hypotension due to exaggerated release and response to chemical mediators released from the mast cells or basophils. ${ }^{17}$ An effective approach to the differential diagnosis and management of hypersensitivity reactions during anesthesia has been detailed elsewhere. ${ }^{18}$

Proper timing of laboratory studies, such as blood and urine tests can be helpful in distinguishing hypersensitivity reactions from other causes. Serum $\beta$-tryptase, an enzyme predominantly stored in the secretory granules of mast cells, provides a useful diagnostic tool to evaluate a suspected hypersensitivity reaction. Mast cell degranulation during hypersensitivity reactions results in an increase in serum tryptase which may be detected 15 to 30 min after the antigen challenge, peaks at one to two hours, and declines with a half-life of about two hours. Therefore, the optimal testing interval is between one and four hours after an event. ${ }^{19}$ Serum tryptase is not increased in hypersensitivity reactions in which mast cell activation did not occur (e.g., direct complement activation). Post hoc diagnosis of hypersensitivity reaction can be established from measurement of serum tryptase. Once a serum sample has been drawn, $\beta$-tryptase is fairly stable, and in vitro decay occurs more gradually than in vivo, making it possible to detect elevated tryptase levels in serum stored at room temperature for days to weeks and in frozen serum for months to years after the suspected allergic reaction. This allows retrospective confirmation that an event was caused by hypersensitivity reaction.

Increased serum histamine concentrations are rarely captured because of histamine's short half-life (102$120 \mathrm{sec}$ ). To detect elevated serum histamine, blood sampling must be done within ten minutes of the event. Since reacting patients frequently require resuscitation, blood sampling for histamine levels is not a priority. Consequently, elevated serum histamine is rarely captured during severe hypersensitivity reactions. Furthermore, interpretation of plasma histamine is clinically problematic because blood specimens must be processed immediately to prevent spontaneous histamine release from basophils which may result in 
artefactually elevated histamine concentrations. Urinary histamine and its metabolites are increased for a longer time. Therefore, measurement of urinary $\mathrm{N}$-methylhistamine $e^{20}$ is a diagnostic alternative that confirms that histamine was released during the adverse reaction.

In general, the definitive diagnosis of anaphylaxis is based on the finding of specific IgE by positive skin test. In our patient, the allergy skin testing was negative, suggestive of a non- $\operatorname{IgE}$ mediated hypersensitivity reaction. A positive skin test to a suspected allergen is considered highly specific proof of an anaphylaxis. A positive immediate response to HES with allergy skin testing has been reported only once. ${ }^{21}$ Furthermore, Ebo et al. ${ }^{8}$ used an in vitro method based on IgE-sensitized basophils to diagnose anaphylaxis to HES.

Severe hypersensitivity reactions to HES are mostly reported as anaphylactoid. ${ }^{12,13,15,22,23}$ Using an enzyme-linked immunosorbent assay, Kraft et al. ${ }^{24}$ demonstrated absence of anti-HES antibodies in sera from 1,056 patients, concluding that preformed HES-reactive antibodies either do not exist in humans or are extremely rare. Dieterich et al. ${ }^{14}$ prospectively studied the frequency of antibody formation due to HES in 1,004 patients and only one patient developed transient antibody formation. This low HES antigenicity can explain generally excellent tolerance of HES compared with other plasma expanders. ${ }^{14}$ Very infrequently HES-reactive antibodies are demonstrated in the sera of patients who experience intraoperative anaphylaxis. ${ }^{6}$ Kreimeier et al. ${ }^{6}$ retrospectively showed HES-reactive antibodies from preoperative blood samples. They reported that following an anaphylactic episode anti-HES IgE concentration decreased sharply, reflecting consumption of the antibodies induced by administration of antigen. However, repeated testing eight weeks later detected anti-HES specific IgE suggesting that the initial event was indeed anaphylaxis. The mechanism of formation of anti-HES immunoglobulins remained unclear, as this patient's history of exposure to HES was not discussed. ${ }^{6}$

In conclusion, the temporal relationship of hetastarch administration to sudden cardiovascular collapse, bronchospasm and urticarial rash in this patient associated with increased serum tryptase and urine $\mathrm{N}$-methyl-histamine, suggests a severe hypersensitivity reaction. Absence of evidence of prior sensitization and a negative skin test are consistent with an anaphylactoid reaction to high MW hetastarch Hextend ${ }^{\circledR}$.

\section{References}

1 Wilkes NJ, Woolf RL, Powanda MC, et al. Hydroxyethyl starch in balanced electrolyte solution (Hextend)-pharmacokinetic and pharmacodynamic profiles in healthy volunteers. Anesth Analg 2002; 94: 538-44.

2 Gan TJ, Bennett-Guerrero E, Phillips-Bute B, et al.; Hextend® Study Group. Hextend, a physiologically balanced plasma expander for large volume use in major surgery: a randomized phase III clinical trial. Hextend Study Group. Anesth Analg 1999; 88: 992-8.

3 Ring J. Anaphylactoid reactions to plasma substitutes. Int Anesthesiol Clin 1985; 23: 67-95.

$4 \mathrm{Beez} M$, Dietl $\mathrm{H}$. Retrospective consideration of the incidence of anaphylactoid reactions following administration of Plasmasteril and Longasteril (German). Infusionsther Klin Ernahr 1979; 6: 23-6.

5 Ring J, Messmer K. Incidence and severity of anaphylactoid reactions to colloid volume substitutes. Lancet 1977; 1: 466-9.

6 Kreimeier U, Christ F, Kraft D, et al. Anaphylaxis due to hydroxyethyl-starch-reactive antibodies (Letter). Lancet 1995 ; 346: 49-50.

7 Laxenaire MC, Charpentier C, Feldman L. Anaphylactoid reactions to colloid plasma substitutes: incidence, risk factors, mechanisms. A French multicenter prospective study (French). Ann Fr Anesth Reanim 1994; 13: 301-10.

8 Ebo DG, Schuerwegh A, Stevens WJ. Anaphylaxis to starch. Allergy 2000; 55: 1098-9.

9 McHugh GJ. Anaphylactoid reaction to pentastarch. Can J Anaesth 1998; 45: 270-2.

10 Mertes PM, Laxenaire MC, Alla F; Groupe d'Études des Réactions Anaphylactö̈des Peranesthésiques.

Anaphylactic and anaphylactoid reactions occurring during anesthesia in France in 1999-2000. Anesthesiology 2003; 99: 536-45.

11 Ring J. The anaphylactoid reaction after colloid infusion (German). Fortschr Med 1977; 95: 2481-4.

12 Porter SS, Goldberg RJ. Intraoperative allergic reactions to hydroxyethyl starch: a report of two cases. Can Anaesth Soc J 1986; 33: 394-8.

13 Bothner U, Georgieff M, Vogt NH. Assessment of the safety and tolerance of $6 \%$ hydroxyethyl starch (200/0.5) solution: a randomized, controlled epidemiology study. Anesth Analg 1998; 86: 850-5.

14 Dieterich HJ, Kraft D, Sirtl C, et al. Hydroxyethyl starch antibodies in humans: incidence and clinical relevance. Anesth Analg 1998; 86: 1123-6.

15 Kannan S, Milligan KR. Moderately severe anaphylactoid reaction to pentastarch $(200 / 0.5)$ in a patient with acute severe asthma. Intensive Care Med 1999; 25: 220-2.

16 Currie M, Kerridge RK, Bacon AK, Williamson JA. Crisis management during anaesthesia: anaphylaxis and allergy. Qual Saf Health Care 2005; 14: e19.

17 Mertes PM, Laxenaire MC. Allergic reactions occurring during anaesthesia. Eur J Anaesthesiol 2002; 19: 
240-62.

18 Hepner DL, Castells MC. Anaphylaxis during the perioperative period. Anesth Analg 2003; 97: 1381-95.

19 Fisher MM, Baldo BA. Mast cell tryptase in anaesthetic anaphylactoid reactions. Br J Anaesth 1998; 80: 26-9.

20 Kaliner M, Dyer J, Merlin S, et al. Increased urine histamine and contrast media reactions. Invest Radiol 1984; 19: 116-8.

21 Takada M, Tomatsu T, Harada T, Murakami N, Shimonaka H, Dohi S. Bronchospasm due to anaphylactic reaction to Hydroxyethyl starch (HESPANDER) (Japanese). Masui 1997; 46: 397-400.

22 Collins JA, Litwin MS, Lutz H, et al. To which extent is the clinical use of dextran, gelatin and hydroxyethyl starch influenced by the incidence and severity of anaphylactoid reactions? Vox Sang 1979; 36: 39-49.

23 Cullen MJ, Singer M. Severe anaphylactoid reaction to hydroxyethyl starch. Anaesthesia 1990; 45: 1041-2.

24 Kraft D, Sirtl C, Laubenthal H, et al. No evidence for the existence of preformed antibodies against hydroxyethyl starch in man. Eur Surg Res 1992; 24: 138-42. 